\title{
The Legal Ups and Downs of Part-Time Contracts in Spain [A Report on 36 Years of Normative Regulations (1980-2017)]
}

\author{
Sara Ruano-Albertos \\ Labor Law and Social Security University, University Jaume I of Castellón, Castellón, Spain \\ Email: ruanos@uji.es
}

How to cite this paper: Ruano-Albertos, S. (2018). The Legal Ups and Downs of Part-Time Contracts in Spain [A Report on 36 Years of Normative Regulations (19802017)]. Beijing Law Review, 9, 15-38. https://doi.org/10.4236/blr.2018.91002

Received: January 25, 2018

Accepted: March 6, 2018

Published: March 9, 2018

Copyright $\odot 2018$ by author and Scientific Research Publishing Inc. This work is licensed under the Creative Commons Attribution International License (CC BY 4.0).

http://creativecommons.org/licenses/by/4.0/

\section{Open Access}

\begin{abstract}
The purpose of this work is none other than to highlight the process of contract flexibilization through part time through the continuous regulatory changes that have been happening up to the present time. For this, a study of the normative evolution has been carry out, as well as of the statistical reports that allowed us to appreciate the increase in its use.
\end{abstract}

\section{Keywords}

Part-Time Work, Spain, Europe Union, Temporary Work

\section{Introduction}

For many years, the part-time contract was barely implemented in Spain and it represented about $4 \%$ of all work contracts ${ }^{1}$, which was a very low percentage compared to other European countries. For both legal and cultural reasons, a part-time contract was conferred a residual, and almost testimonial, use, which was linked above all to seasonal activities. It was initially devised to facilitate females' access to work by allowing them to combine work with family obligations (still highly feminized). Later the part-time contract came to the forefront as an ideal formula to lower excessively high unemployment figures, just as the lawmaker has expressly indicated in the preambles of several reforms in which this contractual figure has been the object, even when females mainly predominate.

Its legal regime has been the object of a constant adaptation process on a par with the new ways of organizing work that respond to a services society model. This constant adaption has indeed gradually increased, and has peaked in recent ${ }^{1}$ Source: "Anuario de Estadísticas Laborales", Ministerio de Trabajo y Asuntos Sociales. Encuesta de población activa. II trimestre de los años 1987-1996. Madrid. 
times by becoming more appealing to employers because it can cover their interests. The need to distribute a scarce asset (work) has led the lawmaker to incline the balance towards the business side by succumbing to its demands to the detriment of the other part of the contract: workers have to involuntarily face part-time work. Thus, initially, no balance was stuck between workers' individual availability and companies' organization strategies. Nowadays, workers access the labour market mainly by temporary and part-time contracts and, even after recently perceiving an incipient improvement in the labour market with lower unemployment rates, this improvement has not been translated into employees' working conditions in the same way. In fact, a new gap is opening on the working market which, in this case, is between full-time employees' working conditions and the working conditions of workers with temporary/part-time contracts. The combination of both contract forms is a current labour market trend, and the vulnerability of these workers is evident: unstable work, very low wages, difficulty accessing Social Security benefits. In short, labour is at increasing poverty risk that affects workers, but also influences the impoverishment of the Spanish society as a whole.

The part-time contract originally conceived to facilitate the incorporation of women into employment, as a way of working to reconcile family and professional life, has been suffering over time a continuous process of flexibilization. A process that takes place alongside the new forms of work organization that respond to a model of a service society; but this flexibility, in this philosophy of eliminating rigidities, breaks the initially intended balance between the individual availability of his time by the worker and the strategies of organization of production of enterprises, succumbing exclusively to the interest of only one of the parties: the company.

\section{From the Initial Restriction in Its Subjective Area to Its Complete Generalization}

Today a part-time contract can be signed with any workers without it being restricted to certain groups, which was the case in the past. The simple fact that both parties are willing to sign a work contract suffices to set a shorter working day than that generally applied. So there is no subjective or objective limit, which occurs in other forms of contracts, such as causal temporary contracts (subject to the objective causality principle in contracts) or those of a subjective kind, which occurred with indefinite contracts virtually disappearing to encourage indefinite contracting, which was restricted to certain groups. This statement must be pointed out when part-time contracting is carried out in the retirement area to allow access to early retirement or to voluntarily delay retirement. Beyond this domain, in which strict legal demands result from the need to ensure that a feasible pensions system is maintained, this contracting type lacks objective (type of work) or subjective (groups of workers) limits. This generalisation was made when it was first set up with the first legal reforms (1984), thus the initially 
established subjective limitation ${ }^{2}(1980)$ was short-live.

\section{Defining the Part-Time Condition and Changes in the Reference Time Module}

The definition of the part-time contract has been the object of successive reforms with the afore-cited purpose of promoting its use. If initially (Workers Statute-1980) the part-time condition limit was set as two thirds of the usual working day for whatever work was being considered, after several legislative ups and downs ${ }^{3}$, the dividing line is now placed on a full-time employee's working day, comparable with the same type of work contract signed to do an identical or similar job, and understood as a full-time worker in the same company or work centre. Only if this work is missing in the work centre/company is the full-time full-time working day resorted to, which is contemplated in the collective agreement or, if it were the case, the maximum legal working day. Therefore, today it is enough for a worker to offer his/her services during a shorter working day to that which corresponds to a full-time worker for him/her to be considered a part-time worker.

It is also interesting to point out that the comparable worker is not a worker from the same sector or from any other, but the focal point for a comparison is initially centred on the worker who offers his/her services in the same work centre (the company by default) by doing an identical or similar job. So as a general rule, the lawmaker has fled from an overall definition by moving towards the worker's closer circle.

Another interesting point from the constant adaptation perspective of this contract-based type is the time-related module for the possible practice of reducing the working day as it can be presently annually calculated together with the daily, weekly and monthly working times. This annual calculation doubtlessly allows companies' productive organisation systems, as well as workers' personal or family circumstances, to be better adapted, although the second reason was likely less important in the legistoris volutatis than the first one. Even though the lawmaker has not always adopted a clear criterion about this point, today the annual calculation of the working day is very well-established ${ }^{4}$.

\section{The "Extended Working Day" in the Part-Time Contract: Additional Hours and Overtime}

The possibility of extending the working day as a portion of part-time work is a ${ }^{2}$ Temporary Prevision, $3^{\text {rd }}$, WS-1980. The following groups could be contracted part-time: a) workers paid unemployment benefit; b) those who are no longer paid unemployment benefit, but still cannot find a job; c) farmworkers who have become unemployed; d) youths under the age of 25 years.

${ }^{3}$ Until the current definition came into being (dates back to 2001), the lawmaker progressively extended the delim-iting percentage (set in 1998 at 77\%) and the type of working day (in 1998, the estimated module was the maxi-mum conventional working day or, by default, the maximum legal working day).

${ }^{4}$ Law 2/1984 of 2 August cancelled the annual reference, which was reintroduced by Law 10/1994, of 19 May and remains until the present-day. 
good indicator of this contractual figure's flexibility. Although working overtime in proportion to an agreed working day was allowed when it first came into being (1984), years later (1998) overtime was forbidden, save that foreseen due to urgent requirements ${ }^{5}$ or to force majeure ${ }^{6}$. This prohibition came about simultaneously with the creation of a new and extremely similar concept with the same purpose, but also one that was typical of a part-time contract: "additional hours", defined as the hours that can be worked having been agreed on apart from the normal working hours agreed on in the part-time contract. It is still unwonted that such working hours should be make legal after doing away with overtime, and it was stressed that they are not of the same type as the hours worked as overtime. Their use was encouraged as it would not seem a good thing to combine a reduced working day, which is typical of a part-time contract, with working overtime on a regular basis. Effectively complying with one of the advantages maintained for this contract to be used also seems difficult: a worker combining his/her family and working lives.

Additional hours are normal working hours whose singularity lies in them being expressly agreed on by the employer and the worker as an extension of the working day initially agreed on. They are paid according to not only the same conditions as usual working hours, but also to the same bases and rates as ordinary working hours, and should feature as such in the documents that reflect payments and salaries being paid. In short, it is a matter of having a flexible quantity of hours that allows the working part-time day to be extended until the maximum limit, at the time they were introduced, of $77 \%$ of a full-time working day. Nonetheless an attempt was made to respond to trade union demands for more stable work, but initially the additional hours agreement was possible only in indefinite contracts. This pact had to indicate the number of additional hours that could be worked and that the employer might require, with a legally set maximum level of $15 \%$ of the normal working hours foreseen, and a percentage that collective agreements in the sectorial domain, or in an inferior domain, could increase up to as a maximum of $30 \%$. Regulations on their distribution and the way to work the additional hours agreed on were also attributed to collective agreements (sectorial or from an inferior domain). One of the foreseen novel aspects in regulations was particularly interesting: the worker's right to establish the additional hours (completely or partially) to be worked, which amended the normal working day initially agreed on.

Notwithstanding, part-time contracting remained in a deadlock, which led to a new legal reform $(2001)^{7}$ hat also affected agreements on additional hours, whose possibility remained by their distribution and the way they were worked being transferred to the applied collective agreement (Casas Baamonde, 2000; Cavas Martínez, 2001: pp. 47 and next; Goerlich Peset, 2001: p. 10; Escudero ${ }^{5}$ Law 32/1984, of 2 August.

${ }^{6}$ Royal Decree-Law 15/1998, of 27 November, urgent measures to improve the labor market in relation to part-time work and the promotion of its stability.

${ }^{7}$ Royal Decree-Law 5/2001, of 2 May; after its processing in parliament as a Draft Bill, it led to Law $12 / 2001$, of 9 July, being enacted. 
Rodríguez, 2001). This non-specific transfer to the applied collective agreement meant opening up this faculty to the collective agreement of any area, which was previously evidenced initially in sectorial agreements that offered better guarantees by being negotiated by more representative trade union organisations. Moreover, the worker's right to consolidating additional worked hours was cancelled, which thus excluded the stable increase in his/her ordinary working day. The limit of additional hours that could be agreed on in the collective agreement was extended to $60 \%$ of the hours that featured in the contract. As to how these hours were distributed, the three-monthly distribution module disappeared, as did the possibility of the worker freely cancelling the agreement reached about additional hours, which always had to be causal ${ }^{8}$. Although the worker had to be notified 7 days beforehand about the time and day when additional hours were to be worked, the new reform allowed the agreement to stipulate something else, which implied it was set totally free by the collective agreement because this availability was not previously possible as the regulation imposed it. We ought to remember that the same reform did away with the top percentage of a working day (77\%) that marked the limit between working full-time and working part-time.

Years later $(2012)^{9}$ during the financial crisis, which had a strong impact in Spain and many jobs were destroyed, part-time contracts were once again reformed. For the theme dealt with herein, workers were allowed to work the overtime set legally in proportion to the agreed working day, which was calculated according to the rates at which Social Security payments were made and to regulatory bases of benefits. Thus the legal regimes of both contract types came closer to one another: the adaptation which the Preamble of reforming regulations referred to as an objective was to make part-time contracts precarious by allowing overtime to be worked, whose maximum legal limts were not calculated if compensated with rest periods. If to this we add the fact that these same regulations included the possibility of the employer irregularly distributing part of his/her workers' annual working time (both full- and part-time) [5\% according to Spanish Royal Decree 3/2012, and 10\% according to Law 3/2012], the margin of this adaptability was to have considerably extended without the minimum prior notification (then 5 days) set to favour workers contradicting this statement.

The way unemployments ${ }^{10}$ figures moved and several legal announcements ${ }^{11}$ determined a new reform of the part-time contract only 1 year later. Nowadays this regulation acts as a fundamental centre ${ }^{12}$, although complementary regula-

\footnotetext{
${ }^{8}$ The foreseen causes were: a) attending the family commitments described in Article 37.5 of this Law; b) For training requirements, as determined in regulations, provided an incompatible schedule is accredited; c) Incompatible with another part-time contract.

${ }^{9}$ RDL 3/2012, of 10 February, on urgent measures to reform the labour market. After its processing in parliament, it was passed as Law 3/2012, of 6 July.

${ }^{10}$ The unemployment rate stood at $26.94 \%$ in the first quarter of 2013 . INE. Encuesta de Población Activa. Serie histórica

${ }^{11}$ EU Supreme Court of Justice on 22 November 2012 (the Elbal Moreno matter), and later Regulation STC 61/2013, of 14 March.

${ }^{12}$ Art. 12 workers Statute (2015).
} 
tions have been issued later or the codifying legislation of the Workers Statute (WS) in force was passed (Royal Decree (RD) 2/2015, of 23 October). Indeed RDL 16/2013, of 23 December, on Measures to Favour Stable Contracting and to Improve Workers' Employability, included major changes in contracting and flexibility as to how working hours were organised in part-time contracts (Rodríguez-Piñero y Bravo Ferrer et al., 2014). These changes affected several aspects of its legal regime. So even though the prohibition of overtime was re-established (Cabeza Pereiro, 2013: p. 104) save the overtime needed to prevent or put right accidents, and any other extraordinary and urgent damage, the legal regime of additional hours was further adapted, as, on the one hand, they were allowed in temporary part-time contracts (provided the working day equalled or exceeded 10 hours/week in annual calculations) and, on the other hand, the maximum legal limit was raised to $30 \%$. One particularly relevant aspect was the reduction in what was then the meagre prior notification time that a worker had the right to, which was cut to 3 days, and empowered the collective agreement to reduce it, but not to prolong it.

The ample faculties conferred to social stakeholders are significant to shape a broader flexibility margin, which causes a change of perspective in the role conferred to the collective negotiation that is normally able to better workers' protection by improving legal regulations. From 2013 collective agreements can adapt the legal regulation set to favour the business use of part-time contracts, but not to place obstacles to their agreement with or without restrictions to the legal system. Thus the collective agreement can raise the maximum limit of additional hours that can be agreed on (with the $60 \%$ limit), but the minimum limit (30\%) cannot be lowered. However, the agreement can cut the prior notification time to be called to work additional hours, without it being ready to be applied, which had occurred before. The legal regulation has become a minimum not available for collective negotiations, but is only able to increase both adaptation parameters.

Other modifications include: 1) doing away with the preference to occupy vacant job posts worked either full-time or part-time, depending on each case, to favour those workers who had previously agreed to voluntarily convert contracts; 2) reducing the unemployment contribution by $1 \%$ for part-time contracts signed for a given time; 3 ) abolishing the call for collective negotiations to establish requirements or specialities to convert full-time contracts into parttime ones for certain reasons (family relations or training).

One particularly important aspect was forecasting companies' registration obligations, copies for workers and conserving documents about part-time workers' working day (except for family home services) as a guarantee-based counterweight in this ever-growing adaptation, as the next epigraph points out.

\section{Controlling and Following up the Part-Time Working Day}

The fuzzy dividing line that characterises full-time and part-time work has not 
gone unnoticed by the lawmaker, who has established a business obligation to control that the hours worked by part-time workers have been actually carried out on a daily basis. This is a specific legal precaution, and an essential one, because this form of contracting moves away from rendering services subject to the ordinary pacted day's limit.

It is evident that adapting the working day can increase regulations on the working day not being met to the detriment of workers' rights, who may have to face working hours without being necessarily and fairly paid. These difficulties can multiply when the working day is irregularly distributed and working days are performed by employees with part-time contracts of a given duration; they can only legally extend their working day by working the additional hours agreed on. Monitoring and controlling rules about limits to a working day become highly relevant if a dwindling balance between both the parties of the contractual relationship is to be struck. Furthermore, it is necessary to consider the repercussion that more irregularly worked hours may have on contribution payments because this matter not only affects the worker, but also the Social Security's economic resources.

All in all, having to record workers' daily working days has not free of controversy, and distinct criteria about it have been adopted: although initially the National Court ${ }^{13}$ considered that the obligation of taking records had to be extended to all workers, no matter what type of working day featured in the contract (full- or part-time), later the Supreme Court corrected this interpretation. For the National Court, the company had to thoroughly record the working day of all its workers, regardless of either the working day type or all the worked overtime. This interpretation led to Instruction 3/2016 of the State Work Inspection Office being immediately passed, about Intensifying Control in Working Time Matters and Overtime by considering records taken of working days being made compulsory, even though no overtime is worked. This Instruction pointed out that recording the working day should be done on a daily basis, and should include a given entry/exit schedule for each worker. The existence of such a record has to be verified in the work centre to avoid its possible ulterior manipulation.

In later decisions, the Supreme Court ${ }^{14}$ stated that companies are not obliged to take records of the working day of all staff members on a daily basis with a view to checking that working hours and the working day agreed on are indeed being worked because the obligation to record working days is contemplated when controlling overtime, and not ordinary working days. Thus only a daily record of worked overtime must be made. According to the judgement made in the Supreme Court's majority doctrine ${ }^{15}$, among other considerations, this criterion is justified by that set out in Article 12.4c) of the WS on the obligation of ${ }^{13}$ Sentence 207/2015 of the National Court of 4 December 2015 (AS 2016/97).

${ }^{14}$ The Supreme Court's Sentence (SCS) of 23 March 2017 (RJ 2017/1174) partially cancels Sentence 207/2015 of National Court, of 4 December 2015 (AS 2016/97), as did SCS of 20 April 2017 (RJ 2017/1869).

${ }^{15}$ This Sentence relies on three particular votes. 
taking records everyday, and of adding up all the hours worked by each worker with a part-time contract monthly, and it being the employer's obligation to hand a monthly summary of worked hours to employees. This order would be rendered unnecessary if the lawmaker had established the need to record all working days with a system to verify any scheduled agreed on being fulfilled. Basically, the aforecited Decision reasons that when the lawmaker introduces this caution (s)he does so expressly by establishing this obligation for certain assumed cases. This is not the case in Article 34 of the WS, which refers to an ordinary working day. Nonetheless, the aforementioned Decision indicates the lege ferenda of the convenience of reformed legislation clarifying the scope of this obligation to take records in relation to the regulations that control data protection.

In accordance with the Supreme Court's doctrine, the State Work Inspection and Social Security Office considered it worth supplementing its former Instruction with Instruction 1/2017, dated 18 May, which stressed that businesspeople were not obliged to record the hours worked on a working day everyday for full-time contracts and, therefore, does not constitute not taking such records an offence. However, this does not free companies from respecting the legal and conventional limits for working times and overtime. Indeed this Inspection Office can sanction regulations about working times and overtime being broken according tochecks made by inspectors because the mere lack of records being taken of working days does not renounce the control entrusted to the State Work Inspection and Social Security Office. No party escapes the major difficulties encountered by the Inspection Office when checking and testing the limits applied to working days, and it is necessary to reiterate that recording working days on a daily basis is actually a means of documentary proof that doubtlessly facilitates the always difficult task of accrediting possible excesses of working days.

As regards the obligations for part-time contacts set out in Article $12.4 \mathrm{c}$ ) of the WS, Instruction 3/2016 indicates that verifications of working times in parttime contracts have to comply with Instruction 1/2015 about intensifying controls of part-time contracting. Since Instruction 1/2015 has not been affected by any previous instruction, and as it sets out, verifications must be made daily to ensure that the input/output of each part-time contract has been actually made, and any system or means that allows workers' working days, with the respective incoming/outgoing times, to be recorded objectively is considered valid. This implies that presenting the general schedule to be applied in the company or time quadrants devised for certain periods, which were prepared beforehand and, thus, determine work for this period, but not the hours actually worked, for which it is only possible to acquire knowledge a posteriori as a result of recording working days, is not acceptable to accredit this obligation being met. Verification that a record is actually being taken must be made in the work centre, although a businessperson alleging its subsequent accreditation by appearing be- 
fore the Administration is not acceptable. The company must present documents to accredit that all its part-time workers have received a monthly summary of all the hours they have worked, including any additional hours, and that the workers agree with this summary.

In relation to part-time workers, doubts about this obligation have always arisen, which Article 12.4c) of the WS, on day-to-day records of hours worked each month (both normal and additional hours) establishes that this practice is always demanded, even when a worker has not worked any additional hours in a given month, or otherwise, it is demanded and applicable only when additional hours have been actually worked in a given month, regardless of them being agreed on or voluntary. Accordingly, the legal principles understand that "(...) if any worked additional (neither those agreed on or voluntary) hours are lacking in a given month, the working day with the hours worked expressed in the records will completely coincide with what was initially agreed on as normal working hours in the contract, and it would neither be redundant or unnecessary, but would create a further administrative load for companies, which could not be reasonably justified as it would contribute nothing to possibly control a working day by the State Work Inspection Office or by the Social Order Courts"; it can also be argued that: “(...) the regulation of rule h) is located in Section 5 of Article 12 , which is specifically dedicated to the definition and the rules to be applied to additional working hours. No such rule is found in Section 4 of Article 12 of the WS, which refers to general part-time contracting rules. This location helps Courts to reinforce the thesis as “(...) when no additional hours are worked, the working day record not only does not provide any distinct data from those reflected in the part-time contract itself but, by systematically interpreting the regulation to the rule's location, it seems that the latter is included as part of the regulation on additional hours, and in such a way that, if no additional hours have been worked, the obligation of recording the ordinary working day initially agreed on would be waivered"16. As we can see, the same consideration remains and, therefore, we reach the same conclusion which the Supreme Court drew about recording overtime.

However, it is worth opposing, in the first place, the very purpose of such a record for part-time workers, which is none other than introducing this foresight precisely because it moves away from rendering services subject to the ordinary working day limit agreed on so that per se there would be no need for additional hours to exist or not; so this record is necessary to determine if the part-time working day limits are exceeded or not. Secondly, there is the wording in the rule, in Art. 12.4c), which differs from that set out in Article 35.5 of WS. This establishes that: "As regards the calculation of overtime, each workers' working day will be recorded on a day-to-day basis (...)", from which the Court deduces that this control refers exclusively to overtime; however, the rule referred in Article 12.4c) establishes that: "to this end, part-time workers' working

\footnotetext{
${ }^{16}$ The Sentence of the High Court of Justice of Galicia of 24 October 2016 (JUR 2016/250024).
} 
day will be recorded on a day-to-day basis (...)", this section is found in point 4c) of Article 12. Precisely the section immediately before, but in the same point, refers to part-time workers' working day, and indicates that: "In any case, the sum of ordinary and additional worked hours, including those previously agreed on and voluntary ones, shall not exceed the legal limit for part-time work defined in Section 1". Therefore, this is not related exclusively to additional hours, but to the excessive limit of part-time work. It is also worth underlining that when the Supreme Court argues about recording ordinary working hours not being compulsory, it refers precisely to their interpretation being backed "(...) by that set out in Article 12-4-c) of the WS about the obligation of taking day-to-day records and to monthly summing up all the hours worked monthly by part-time workers, where the employer is obliged to hand a monthly summary to workers of all the hours they have worked (...)", from which nothing different can be deduced from what it expressly states.

In any case, monthly reports must be kept for a minimum 4-year period, which exceeds the time that the legal practice establishes in Article 59 of the WS. For the assumed case of obligations to record part-time workers' working days not being fulfilled, they shall be considered to be full-time work done, unless proof of the contrary exists and accredits the part-time nature of the services rendered; in 2015 the number of part-time contracts transformed through an increase in the time agreed to be worked per 100 inspections made was 4.89 contracts $^{17}$. Any employer who does not fulfill these obligations seriously infringes the law (Art.7.5 LISOS law; Law on Offences/Sanctions in Social Order) by breaching the legal demands set out about working times and limits to working days.

Controlling the hours worked in part-time contracts represents a genuine necessity (Ruano Albertos, 2017) given the crude reality of undeclared work: as the 2015 Annual Report of the State Work Inspection Office states: in 2015 the overall number of workers affected by shadow economy detected by the State Work Inspection and Social Security Office came to a maximum of 86,113 workers compared to 70,787 in 2011 . This is an increase of $21.65 \%$ compared to 2011 and of $4.51 \%$ compared to 2014 . Of them all, the type of fraud that led to the greatest increase was that of workers with increments of above $50 \%$ in their working times in part-time contracts, with a total of 8340 workers, and 4043 workers below $50 \%$. We should also note that the highest concentration of non-declared work was found in the hotel trade, followed by commerce, which are precisely the sectors where part-time work is more frequently contracted. The State Work Inspection Office has been checking that the use of such contracts has been abused, thus efforts to control them have intensified by reinforcing campaigns to verify if any assumed and signed part-time contracts actually disguise real full-time contracts, which is normally done to avoid paying higher contributions.

${ }^{17} 2015$ Annual Report of the State Work Inspection Office. 


\section{Social Protection and Working Part-Time}

In a professional contribution-type Social Security model in which employment determines being included in the Social Security system, and paying contributions allows access to certain benefits, and if it is taken as a module to set Social Security quantities, the part-time nature of the work may have an impact of these workers' social protection. Social protection represents a cost for employers, who pay most of the payments made to the Social Security System. Hence the payments in these contracts can be made as an incentive or disincentive of its use, and it is even possible that the norm can reduce these workers' social protection scope by excluding them from the right to some benefits that full-time workers can benefit from, which happened in the past despite it infringing the constitutional equality principle.

When the system of post-constitutional labour relations started (WS-1980), and with part-time work at very low levels, the lawmaker arranged the contributions in these contracts to be made according to the hours or days actually worked. Here the intention was to encourage their subscription as the previous regulation established the minimum amount of statutory minimum wage in force at the time as a minimum contribution payment limit. This limit operated independently of the number of worked hours, which clearly led to its use becoming a disincentive. Some years later in 1993, and once again with the same purpose in mind, the lawmaker paid attention to cut the social cost associated with contracting by reducing the level of protective intensity, and subsequent contribution payments, of those workers who worked fewer than 12 hours/weeks or 48 hours $/$ month $^{18}$. This restriction was eliminated in 1998 , which placed the social protection of part-time and full-time workers on a par as far as benefits were concerned, but not for other aspects, like calculating the grace period and regulatory bases of benefits.

One very controversial matter in the legal control of part-time work has been determining the rule for calculating the grace periods demanded to access any benefits that result from common disease, particularly those that require long periods of prior payments, such as permanent invalidity benefit and retirement. At first, however, the lawmaker did not foresee any rule for this purpose, and solved the matter administratively ${ }^{19}$ by applying the strict rule of proportionality $^{20}$ except for unemployment benefit (in which the working day was calculated as a Social Security payment independently of the working da ${ }^{21}$ ). This rule was later explained as a result of several legal announcements in Spain and elsewhere in the European Union ${ }^{22}$. Nowadays, the rule of proportionality still continues as

\footnotetext{
${ }^{18}$ Social protection rights only included possible occupational accidents and professional diseases, healthcare due to common contingences, maternity leave/benefit and Wages Guarantee Fund; therefore, benefits from common contingences and unemployment were excluded.

${ }^{19}$ Resolution of 1 February 1982 on membership and benefits for workers with part-time contracts.

${ }^{20}$ This strict proportionality consists in finding the equivalent in worked hours in theoretically taxpaying days (achieved by dividing by 5 the number of hours actually worked, the daily equivalent to the calculation of working 1826 hours/year).

${ }^{21}$ Royal Decree 625/1985, of 2 April (Art. 3.4).

${ }^{22}$ EU Supreme Court of Justice on 22 November 201 (Elbal Moreno) and STC 61/2013 of 14 March.
} 
any contributions made are calculated by the number of corresponding hours so that the calculation of part-time work takes into account the hours actually worked $^{23}$. Nonetheless, this very strict rule is explained by applying the overall part-time condition coefficient ${ }^{24}$, which allows the demanded grace period to be reduced for part-time workers according to the less or greater weight that part-time work represents in their Social Security payment career. This hence avoids the difficult access to benefit which demanding these workers to possess a grace period originally devised for full-time workers entails.

The rule of proportionality has also been explained in relation to calculating the quantity of benefits. If initially the regulatory basis for benefits was calculated by applying the same rules as for a full-time worker, that is, using the average Social Security payments base of the temporary periods foreseen for each benefit, nowadays almost all benefits have set singular rules for periods to be taken into account to calculate this average, expect for permanent invalidity allowances and retirement pensions. The peculiarity to calculate the amount of these two benefits (only the permanent invalidity that results from common disease) materialises in determining the percentage to be applied to the regulatory basis to determine the amount of a benefit since the number of days obtained after applying the part-time condition coefficient (specific) increases when a coefficient of 1.5 is applied. This improves the quantity of these benefits by compensating part-time workers' greater vulnerability in those benefits in which a longer or shorter Social Security career influences the application of a higher or lower percentage on the regulatory base. However, the lawmaker has not been so generous in other important aspects like the mechanism used to include gaps in these contracts, carried out using the minimum Social Security payment base from among those that can be applied at any time, which corresponds to the number of hours ultimately contracted. Bearing in mind the number of hours exclusively worked in last contracts, although it is a neutral forecast that can benefit or harm workers, implies the lawmaker moving away from the weighting that stems from applying the overall part-time condition coefficient.

\section{The Importance of Social Dialogue in Reforming Part-Time Work}

One aspect that is worth indicating is the leading role played by social dialogue in the successive reforms made to part-time work. The Spanish labour market characteristics, including high unemployment rates and precarious job posts that result mainly from temporary contracts, have meant that most legal reforms are

\footnotetext{
${ }^{23}$ The part-time condition coefficient is determined by the percentage of the working day actually worked on a part-time basis in relation to the working day actually worked by a comparable fulltime worker, which will be applied to the period of contracted part-time work. It results in the number of days considered actually tax-paying days during each period. To these days, the worked full-time working days are added.

${ }^{24}$ This overall coefficient is the percentage that represents the number of days worked and accredited as tax-paying days by applying the strict rule of proportionality to the total days contracted throughout one's working life or, otherwise, to the period in fulfilling a grace period is demanded.
} 
the result of the social consensus reached among social stakeholders, or between social stakeholders and the government.

This happened in the reform back in 1997. Although the reform made in 1994 conferred collective negotiation the possibility of irregularly distributing working days via either a collective agreement or an agreement reached between the employer and workers' representatives, the intended flexibleness within the normative framework by undoing legislation had still not given the expected results. Thus opening up debate and reflection as to what extent the economic recovery that occurred during this period was accompanied by improved labour market functioning to permit responding jointly to serious unempoloyment problems, precarious jobs and high job rotation, could not be postponed. This debate about employment politics also took place in the most representative business and trade union organisations in the state domain, and resulted in the Interconfederal Agreement about stable work of 7 April 1997. This agreement, which was signed by the most representative Spanish trade union organisations (CEOE, CEPYME, CC.OO and UGT) opted, as far as part-time contracting was concerned, for improving its social protection. The adopted agreements included the need to consider equal part-time workers, who worked fewer than 12 hours/week or 48 hours/month, to other workers as regards the general benefits scheme, but without forgetting the need to start the measures set by the Additional Regulation seventh 2, the General Social Security Law, to determine grace periods and to calculate Social Security payments. This normative demise took place in two phases, a form which the Executive Branch of the Government has accostumed the Spanish to in recent decades: an urgent norm (RDL 8/1997, of 16 May), which was later processed as a Draft Bill (Law 63/1997, of 26 December). This Draft Bill once again referred to the social consensus (previously consulted with the most representative trade union and business organisations) when the government was qualified to adopt any necessary provisions to make the right to cover all the possibilities of part-time contracts with fewer than 12 hours/week or 48/hour month effective.

This reform carrieds out only 1 year later sank its roots in social dialogue, in this case between the Government and trade union organisations, but not with business ones, in another sample of negotiated legislation. Specific debate started about how the labour market operated when seeking solutions to high unemployment rates $(20.8 \% \text { in } 1997)^{25}$ and making work stable. This process peaked when the "Agreement on Part-Time Work and Promoting its Stability" was adopted, and with the agreement reached between the government and Spanish Trade Unions CC.OO and UGT on 13 November 1998, which was the basis of Royal Decree 15/1998, of 27 November, whose contribution to part-time work has already been mentioned.

However, social dialogue has not been limited exclusively to Spain. In Europe, part-time work has been established as the only leading figure in the social di-

${ }^{25}$ Source: “Anuario de Estadísticas Laborales". 
alogue process: on 6 June 1997, a framework agreement was reached on parttime work by UNICE, CEEP and CES to describe the general principles and the minimum conditions related to part-time work based on this general framework acting to eliminate discriminations related with part-time workers and to help develop part-time work possibilities with an acceptable base for employers and workers alike. Within the framework of normative technical processes of Community Law, this above-cited Agreement was the object to be covered by Council Directive 97/81/EC on the framework agreement on part-time work, a community regulation which, however, the lawmaker did not pay attention to when the aforementioned Royal Decree 15/1998, of 15 November, was passed which, as pointed out, returned to the percentage-based system to define a part-time contract. This meant that the lawmaker moved away from the cited Directive, and also from the International Labour Organisation [Agreement no. 175 (1994)] which, like the above-mentioned Directive, defines part-time workers as people's work that simply lasts fewer hours than that of full-timer workers, but is in a comparable situation. At the time, the definition of part-time work based on a percentage of an ordinary working day was considered a useful instrument to do away with fraud that came about from the definition introduced by the 1994 reform, which allowed this percentage to ensure part-time workers' social protection in terms of that compared with full-time ones.

Social dialogue processes in Europe on this matter do not end in the aforementioned social dialogue/agreement. Much more recently, and as a result of youth unemployment problems, the most representative social interlocutors in Europe signed the framework agreement on youth employment actions to be taken. In Spain, however, the necessary consensus was not reached, and the government dealt with the matter using an emergency regulatory procedure: Royal Decree 4/2013 of 22 February, about measures to support entrepreneurs, to stimulate growth and to create jobs. Subsequent Law 11/2013, of 26 July, set out incentives to contract youths by lowering the Social Security rate paid by the microenterprises that signed indefinite contracts, and for part-time contracts linked to training unemployed youths ${ }^{26}$.

Notwithstanding, the part-time contract was still thought to be susceptible to provide more possibilities to lower very high unemployment rates as it was considered an effective formula from the production organisation viewpoint, although as pointed out, it was not especially appealing for workers in social protection matters. The social consensus was a determining factor to provide an opening for the situation created as a result of the above-mentioned legal announcements which questioned the insuitability of national regulations for community regulations, and even to the Spanish Constitution: the European Union Supreme Court of Justice of 22 November 2012 (Elbal Moreno) (Garcia Ninet \& Vicente Palacio, 2013) and the later Regulation STC 61/2013 of 14

${ }^{26}$ Along these lines, this Law introduced an amendment about the original RDL outline by extending the subjective area to those workers who had no official compulsory education qualification, vocational training qualification or a certificate of professionalism (Art. 9, Section 2d). 
March on the equal treatment principle between men and women, were announced about the rules to calculate during Social Security periods in part-time contract, where the latter declared null the rules to calculate grace periods as being inconstitutional given the right to a retirement pension where the corrective measures of the strict rule of proportionality in calculations, introduced by Royal Decree 15/1998, did not help to diminish discriminatory treatment ${ }^{27}$. The nullity of this regulation led to a new agreement being signed between the government and social interlocutors (an agreement of 31 July 2013 to improve conditions so that part-time workers can access social protection). The content of this agreement was transferred to the Royal Decree 11/2013, of 2 August, to protect parttime workers and other urgent socio-economic measures after its processing in parliament determining Law 1/2014, of 28 February being enacted, whose content was included in the new codifying legislation of the General Social Security Law passed by Royal Legislative Decree 8/2015 of 30 October.

\section{The Part-Time Contract and Temporary Work: A Brief Historic Contextualization of Its Relations}

The evolution of part-time work cannot be understood without paying attention to the normative context in which it has taken place, specifically in the legal control content of a contract with a given duration or temporary contracting.

In the 1980s, high unemployment rates determined specific regulations being passed, which allowed non-causal temporary contracting or job creating, which went against the traditional causality rule in contracting. Such non-causal temporary contracting was, initially (1981), restricted to the groups most affected by unemployment, and ended up being generalised (1984) for all unemployed workers, which marked the start of the characteristic Spanish market segmentation. It is also necessary to remember that, initially, the part-time contract also had subjective limitations, and was shaped more as a mechanism to encourage employment than a normal way towards flexible contracting, and this limitation was not suppressed until 1984.

Despite the normative efforts made that motivated the number of part-time contracts to increase between 1985 and 1993, which went from almost 2 million in absolute terms to 2,547,611 in 1985 and to 4,432,547 in 1993, the number of unemployed persons in Spain was still high. In fact by the end of 1993, the unemployment rate in Spain was $22.7 \%{ }^{28}$. Thus the formulae applied until then were evidently not producing the expected results. Consequently, diverse normative modifications were to occur in an attempt to establish an occupational relations framework that, on the one hand, adapted to the changing circumstances of production processes and technological innovations and, on the other

\footnotetext{
${ }^{27} \mathrm{As}$ indicated, these rules referred to calculating "theoretical tax-paying days" by dividing the number of hours actu-ally worked by 5 and applying a multiplier coefficient of 1.5 to the result. By applying these rules, and with a 4 -hour/week work contract, the female worker in the dispute in question would need to work 100 years before having the right to a retirement pension.

${ }^{28}$ Source "Anuario de Estadísticas Laborales", Ministerio de Trabajo y Asuntos Sociales.
} 
hand, to respond to the high unemployment rates which continued with time (Rodríguez-Piñero y Bravo Ferrer, 1985: p. 57). However, levels of voluntary part-time work were very low and the main factor for men and women to do part-time work was none other than the kind of working activity rather than personal choice. Indeed female part-time wage-earners represented 14 per 100 wage-earners in 1993, while their mail counterparts represented 2 per 100. It was significant that the cause alleged as being related to family responsibilities for women to work part-time barely represented 9 per 100 as opposed to 43 per 100 who attributed it to type of working activity ${ }^{29}$ being undertaken. Domestic work predominated for this last group of women (almost one third), which thus supported the idea that women's professional and occupational segregation in the labour market was the main reason for them having a part-time contract.

Despite it being clear that part-time contracting had relatively increased, it had not increased at the same levels as in other North European countries; the number of part-time contracts in $1985^{30}$ in Spain came to $123,849(4.86 \%)$ and 358,533 (7.03) in 1989. For this reason, Royal Decree-Law 3/1993, of 26 February, attempted to promote using this contract type by extending the benefits set out in Law 22/1992, of 30 July, on transferring urgent measures to encourage job creation and protection from unemployment to indefinite part-time contracts signed in compliance with that set out in this law. It must be taken into account that the temporary working condition had considerably increased as the number of temporary contracts went from $2,547,611$ in 1985 to $4,432,547$ in $1993^{31}$. It was not until $1994^{32}$ that using temporary contracts to encourage job creation was cancelled as the lawmaker opted to address job creation policies to encouraging indefinite work contracts and to re-establish the objective or causality principle, even when contracting is done through the legalised Part-Time Employment Agencies that had recently appeared on the scene (1994).

Thus the temporary working condition is still a chronic problem for the Spanish labour market that has found other legal ways to maintain its hegemony, and this same temporary working condition is predicted from part-time contracting, whose increase in recent years has been temporary in nature, as the data below (Table 1) clear express:

Stable job creation has never been well-established, not even at times when job creation grew in Spain linked to the Spanish property bubble (2001-2008). Instead temporary contracting was the main form of job contracts despite its causal

\footnotetext{
${ }^{29}$ CES Report: La situación de la mujer en la realidad socio laboral española. Aprobado por el Pleno del Consejo Económico y Social el 19 de octubre de 1994.

${ }^{30}$ Source: "Anuario de Estadísticas Laborales", Ministerio de Trabajo y Asuntos Sociales. Encuesta de población ac-tiva. II trimestre de los años 1987-1996. Madrid.

${ }^{31}$ Source: "Anuario de Estadísticas Laborales", Ministerio de Trabajo y Asuntos Sociales. Encuesta de población acti-va. II trimestre de los años 1987-1996. Madrid.

${ }^{32}$ Law 10/1994, of 19 May, on urgent measures to promote job creation. Nonetheless, its 3rd D.A maintained tempo-rary contracts in force to encourage job creation, which were signed according to Royal Decree 1989/1984, of 17 October, which controlled temporary contracting as a measure to encourage job creation, with a maximum duration of 3 years, between 1 January and 31 December 1994, which would permit them to be subject to two extensions at the most lasting up to 18 months.
} 
Table 1. Recorded contracts ${ }^{\mathrm{a}}$.

Register Labor Movement

REGISTERED CONTRACTS: Type of contract (Indefinity/Temporary)

(Data to december)

\begin{tabular}{|c|c|c|}
\hline & $\begin{array}{c}\text { C.indefinidos } \\
\text { TOTAL }\end{array}$ & $\begin{array}{c}\text { C. temporales } \\
\text { TOTAL }\end{array}$ \\
\hline 1995 & 26,209 & 523,629 \\
\hline 1996 & 21,140 & 626,472 \\
\hline 1997 & 71,245 & 732,737 \\
\hline 1998 & 67,425 & 821,639 \\
\hline 1999 & 100,774 & 978,594 \\
\hline 2000 & 87,139 & 889,883 \\
\hline 2001 & 87,995 & 871,519 \\
\hline 2002 & 81,287 & 877,050 \\
\hline 2003 & 90,215 & $1,046,255$ \\
\hline 2004 & 91,663 & $1,131,659$ \\
\hline 2005 & 108,480 & $1,221,137$ \\
\hline 2006 & 235,122 & $1,151,161$ \\
\hline 2007 & 134,511 & $1,126,808$ \\
\hline 2008 & 103,061 & $1,014,516$ \\
\hline 2009 & 85,827 & $1,051,738$ \\
\hline 2010 & 93,171 & $1,096,647$ \\
\hline 2011 & 65,678 & $1,099,787$ \\
\hline 2012 & 77,366 & 981,135 \\
\hline 2013 & 83,792 & $1,207,061$ \\
\hline 2014 & 99,853 & $1,284,209$ \\
\hline 2015 & 107,858 & $1,487,057$ \\
\hline 2016 & 122,294 & $1,576,724$ \\
\hline
\end{tabular}

a Source: the author using data from the Spanish Ministry of Employment and Social Security, Statistics, Labour Market, and Registered Occupational Movements.

nature. This same trend has been noted in recent years when unemployment in Spain has dropped below 20\% (data from August 2017), but at the expense of precarious jobs.

For part-time work, the data below (Table 2) reveal a sharp rise in part-time contracting which in 1995 represented only $17.49 \%$ of all signed contracts, but was $33.04 \%$ of all contracts in 2015 (18.38\% in 2000, 23.94\% in 2005 and $28.25 \%$ in 2010). These same data also reveal that the increase in indefinite contracting has been reflected mainly as part-time contracts: in 1995 indefinite part-time contracting represented $26.24 \%$ of all indefinite contracts, in 2015 it represented 
Table 2. Type of contract and type of working day .

Registered labor movement

REGISTERED CONTRACTS: Type of contract and type of working day

(Data to december)

\begin{tabular}{|c|c|c|c|c|c|c|}
\hline & \multicolumn{2}{|c|}{ All contracts } & \multicolumn{2}{|c|}{ Indefinite ones } & \multicolumn{2}{|c|}{ Temporary ones } \\
\hline & Full Time & Part-time & Full Time & Part-Time & Full Time & Part-Time \\
\hline 1995 & 453,628 & 96,210 & 19,330 & 6879 & 434,298 & 89,331 \\
\hline 1996 & 519,974 & 127,638 & 15,325 & 5815 & 504,649 & 121,823 \\
\hline 1997 & 635,278 & 168,704 & 62,342 & 8903 & 572,936 & 159,801 \\
\hline 1998 & 710,068 & 178,996 & 58,618 & 8807 & 651,450 & 170,189 \\
\hline 1999 & 886,329 & 193,039 & 84,961 & 15,813 & 801,368 & 177,226 \\
\hline 2000 & 797,432 & 179,590 & 69,962 & 17,177 & 727,470 & 162,413 \\
\hline 2001 & 766,763 & 192,751 & 72,958 & 15,037 & 693,805 & 177,714 \\
\hline 2002 & 745,400 & 212,937 & 59,793 & 21,494 & 685,607 & 191,443 \\
\hline 2003 & 873,907 & 262,563 & 65,243 & 24,972 & 808,664 & 237,591 \\
\hline 2004 & 934,084 & 289,238 & 66,464 & 25,199 & 867,620 & 264,039 \\
\hline 2005 & $1,011,219$ & 318,398 & 79,272 & 29,208 & 931,947 & 289,190 \\
\hline 2006 & $1,054,955$ & 331,328 & 182,094 & 53,028 & 872,861 & 278,300 \\
\hline 2007 & 942,317 & 319,002 & 97,353 & 37,158 & 844,964 & 281,844 \\
\hline 2008 & 810,896 & 306,681 & 70,327 & 32,734 & 740,569 & 273,947 \\
\hline 2009 & 815,178 & 322,387 & 56,139 & 29,688 & 759,039 & 292,699 \\
\hline 2010 & 853,805 & 336,013 & 60,413 & 32,758 & 793,392 & 303,255 \\
\hline 2011 & 841,541 & 323,924 & 41,036 & 24,642 & 800,505 & 299,282 \\
\hline 2012 & 715,361 & 343,140 & 43,801 & 33,565 & 671,560 & 309,575 \\
\hline 2013 & 877,352 & 413,501 & 48,534 & 35,258 & 828,818 & 378,243 \\
\hline 2014 & 920,708 & 463,354 & 58,235 & 41,618 & 862,473 & 421,736 \\
\hline 2015 & $1,067,954$ & 526,961 & 64,051 & 43,807 & $1,003,903$ & 483,154 \\
\hline 2016 & $1,145,530$ & 553,488 & 71,739 & 50,555 & $1,073,791$ & 502,933 \\
\hline
\end{tabular}

asource: the author using data from the Spanish Ministry of Employment and Social Security, Statistics, Labour Market, and Registered Occupational Movements.

$40.61 \%(19.71 \%$ in $2000,26.92 \%$ in 2005 and $35.15 \%$ in 2010$)$, which indicates a linear increase of 14.37 percentage points. A rise in part-time contracts has also been seen in temporary contracting: in 1995 temporary part-time contracts represented $17.05 \%$ of all temporary contracts, while $32.49 \%$ of all signed temporary contracts were part-time in 2105 (18.25\% in 2000, 23.63\% in 2005 and $24.83 \%$ in 2010), which implies an increase of 15.44 percentage points.

\section{The Importance of the Gender Perspective in Current Legal Regulations on Part-Time Work}

It is also important to point out the importance of high feminisation rates in the 
evolution of controlling part-time work.

Firstly, the lawmaker initially considered this form of contracting a good way to allow women to enter the labour market as it allowed family commitments to be better combined, which were still highly feminised. Available data (see Table 3) show that in 1995, and by taking December as a reference, women's rate of part-time work was $25 \%$ as opposed to that of $12 \%$ for men. Feminisation became more marked with time since in 2015 the part-time rate for women in the selected month rose to $45.44 \%$; that is, a linear increase of 20 points, as opposed to a less marked increase in the part-time rate among males, with only 10 percentage points.

Table 3. Gender, working-time and partial rate ${ }^{\mathrm{a}}$.

Registered labor movement

REGISTERED CONTRACTS: Sex and work time and partiality rate

\begin{tabular}{|c|c|c|c|c|c|c|c|c|c|c|c|}
\hline \multicolumn{4}{|c|}{ TOTAL } & \multicolumn{4}{|c|}{ MEN } & \multicolumn{4}{|c|}{ WOMEN } \\
\hline & & & & & & TOTAL & & & & TOTAL & \\
\hline & TOTAL & $\begin{array}{l}\text { FULL } \\
\text { TIME }\end{array}$ & $\begin{array}{l}\text { PART } \\
\text { TIME }\end{array}$ & TOTAL & $\begin{array}{l}\text { FULL } \\
\text { TIME }\end{array}$ & $\begin{array}{l}\text { PART } \\
\text { TIME }\end{array}$ & $\begin{array}{l}\text { PARTIALITY } \\
\text { RATE }\end{array}$ & TOTAL & $\begin{array}{l}\text { FULL } \\
\text { TIME }\end{array}$ & $\begin{array}{l}\text { PART } \\
\text { TIME }\end{array}$ & $\begin{array}{l}\text { PARTIALITY } \\
\text { RATE }\end{array}$ \\
\hline 1995 & 549,838 & 453,628 & 96,210 & 332,441 & 292,526 & 39,915 & 12.00664178 & 217,397 & 161,102 & 56,295 & 25.89502155 \\
\hline 1996 & 647,612 & 519,974 & 127,638 & 383,762 & 330,019 & 53,743 & 12.00664178 & 263,850 & 189,955 & 73,895 & 28.00644305 \\
\hline 1997 & 803,982 & 635,278 & 168,704 & 470,333 & 400,113 & 70,220 & 14.92984758 & 333,649 & 235,165 & 98,484 & 29.51724717 \\
\hline 1998 & 889,064 & 710,068 & 178,996 & 506,839 & 438,054 & 68,785 & 13.57137079 & 382,225 & 272,014 & 110,211 & 28.83406371 \\
\hline 1999 & $1,079,368$ & 886,329 & 193,039 & 605,887 & 532,923 & 72,964 & 12.04250958 & 473,481 & 353,406 & 120,075 & 25.36004613 \\
\hline 2000 & 977,022 & 797,432 & 179,590 & 535,472 & 470,286 & 65,186 & 12.17355903 & 441,550 & 327,146 & 114,404 & 25.90963651 \\
\hline 2001 & 959,514 & 766,763 & 192,751 & 516,284 & 448,768 & 67,516 & 13.07729854 & 443,230 & 317,995 & 125,235 & 28.25508201 \\
\hline 2002 & 958,337 & 745,400 & 212,937 & 514,433 & 440,674 & 73,759 & 14.33792156 & 443,904 & 304,726 & 139,178 & 31.35317546 \\
\hline 2003 & $1,136,470$ & 873,907 & 262,563 & 601,551 & 511,956 & 89,595 & 14.89399901 & 534,919 & 361,951 & 172,968 & 32.33536292 \\
\hline 2004 & $1,223,322$ & 934,084 & 289,238 & 640,576 & 541,741 & 98,835 & 15.42908258 & 582,746 & 392,343 & 190,403 & 32.67341174 \\
\hline 2005 & $1,329,617$ & $1,011,219$ & 318,398 & 700,780 & 593,304 & 107,476 & 15.3366249 & 628,837 & 417,915 & 210,922 & 33.5416014 \\
\hline 2006 & $1,386,283$ & $1,054,955$ & 331,328 & 732,095 & 622,041 & 110,054 & 15.03274848 & 654,188 & 432,914 & 221,274 & 33.82422178 \\
\hline 2007 & $1,261,319$ & 942,317 & 319,002 & 640,935 & 536,998 & 103,937 & 16.21646501 & 620,384 & 405,319 & 215,065 & 34.6664324 \\
\hline 2008 & $1,117,577$ & 810,896 & 306,681 & 562,045 & 459,114 & 102,931 & 18.31365816 & 555,532 & 351,782 & 203,750 & 36.67655509 \\
\hline 2009 & $1,137,565$ & 815,178 & 322,387 & 594,361 & 479,567 & 114,794 & 19.31385135 & 543,204 & 335,611 & 207,593 & 38.21639752 \\
\hline 2010 & $1,189,818$ & 853,805 & 336,013 & 645,330 & 521,816 & 123,514 & 19.13966498 & 544,488 & 331,989 & 212,499 & 39.02730639 \\
\hline 2011 & $1,165,465$ & 841,541 & 323,924 & 640,952 & 518,059 & 122,893 & 19.17351065 & 524,513 & 323,482 & 201,031 & 38.32717206 \\
\hline 2012 & $1,058,501$ & 715,361 & 343,140 & 576,230 & 441,467 & 134,763 & 23.3870156 & 482,271 & 273,894 & 208,377 & 43.20744975 \\
\hline 2013 & $1,290,853$ & 877,352 & 413,501 & 741,220 & 572,251 & 168,969 & 22.79606595 & 549,633 & 305,101 & 244,532 & 44.49005063 \\
\hline 2014 & $1,384,062$ & 920,708 & 463,354 & 788,262 & 598,717 & 189,545 & 24.04593904 & 595,800 & 321,991 & 273,809 & 45.95652904 \\
\hline 2015 & $1,594,915$ & $1,067,954$ & 526,961 & 904,072 & 690,057 & 214,015 & 23,67234026 & 690,843 & 377,897 & 312,946 & 45.29914901 \\
\hline 2016 & $1,699,018$ & $1,145,530$ & 553,488 & 972,807 & 749,365 & 223,442 & 22,96879032 & 726,211 & 396,165 & 330,046 & 45.44767292 \\
\hline
\end{tabular}

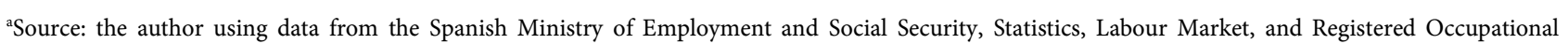
Movements. 
Secondly, this effective feminisation of part-time work has helped to improve the legal statute about part-time work by allowing the EU Court of Justice to start assessing the suitability of Spanish regulations to Directive 79/7 EEC, of 19 December 1978, about the progressive application of the equality principle between men and women in Social Security matters. Indeed the EU Supreme Court of Justice on 22 November 2012 (Elbal Moreno) is a turning point in legally controlling part-time work by announcing the inadequacy of Spanish regulations that expected a proportionally longer working life of part-time workers than full-time workers to access, if applicable, a tax-paying retirement pension whose quantity was proportionally lower due to working part-time. The accused assumed case was the pejorative treatment that stemmed from applying the Spanish regulations in force to a female worker who worked as an employee for more than 18 years, who had been denied a retirement pension because of an large part of her working activity (11 years) was part-time work with short working days, the equivalent to 18.4 of the usual working day in a company, without the multiplying coefficient of 1.5 applied to the theoretical days of Social Security payments being sufficient for her to obtain the minimum grace period expected from paying such payments for 15 years. The fact that this accused assumed case affected a woman, plus the fact that more than $90 \%$ of part-time workers in Spain were women, allowed the Court to evaluate Spanish national regulations, an opportunity that would have not been possible in another case. A few months later the Spanish Constitutional Court reflected this community doctrine in its Regulation STC 61/2013, of 14 March, by declaring inconstitutionality due to discriminatory national regulations, which led to a social agreement and a later legal reform, as previously indicated.

Available data clearly reveal this feminisation of part-time work. By always taking December as a reference of each selected year, as we previously indicated, in 1995 this part-time condition rate for women (full-time and temporary) was almost $26 \%$ as opposed to $12 \%$ for men. This difference has widened.

Another characteristic of part-time work is its high temporariness. As the data in Table 4 reflect, such temporariness has increased in recent years for males (an increase of about 12 percentage points), which has not occurred for women who have shown virtually the same temporariness rate for part-time contracting since 1995.

Part-time work is not only characterised for its feminisation and temporariness, but also for its involuntariness: today's involuntariness rate still comes close to two thirds of all part-time workers. In fact in 2016, the rate ${ }^{33}$ of involuntariness of part-time workers in Spain was $61.9 \%$, as opposed to $27.7 \%$ in the EU. This rate is particularly high for women as it comes close to $60 \%$. Thus female workers' involuntariness is more marked in many aspects: instability in employment, very low salaries and difficulty accessing benefits as it can't be ignored that part-time work affect the bases to calculate Social Security payments

${ }^{33}$ Eurostat. Involuntary part-time employment as percentage of the total employment, by sex and age $(\%)$ 
Table 4. Recorded contracts: gender and duration ${ }^{\mathrm{a}}$.

\section{Registered labor movement}

REGISTERED CONTRACTS: Sex \& contract type and time work

\begin{tabular}{|c|c|c|c|c|c|c|c|c|c|c|c|c|c|c|}
\hline & \multicolumn{5}{|c|}{ TOTAL (Men \& Women) } & \multicolumn{4}{|c|}{ MEN } & \multicolumn{5}{|c|}{ WOMEN } \\
\hline & $\begin{array}{r}\text { TOT } \\
\text { (Undefi } \\
\text { Tempo }\end{array}$ & $\begin{array}{l}\text { AL } \\
\text { ined \& } \\
\text { orary) }\end{array}$ & & Гemp & & $\begin{array}{r}\text { TOT } \\
\text { (Undef } \\
\text { Temp }\end{array}$ & $\begin{array}{l}\text { AL } \\
\text { ined \& } \\
\text { rary) }\end{array}$ & Temp & ry & $\begin{array}{r}\text { TOT } \\
\text { (Unde } \\
\text { \&Temp }\end{array}$ & $\begin{array}{l}\text { TAL } \\
\text { efined } \\
\text { porary) }\end{array}$ & & Temp & \\
\hline & TOTAL & $\begin{array}{l}\text { PART. } \\
\text { TIME }\end{array}$ & TOTAL & $\begin{array}{l}\text { PART } \\
\text { TIME }\end{array}$ & $\begin{array}{c}\text { TEMP. } \\
\text { RATE } \\
\text { PART- } \\
\text { TIME } \\
\text { CONTR. }\end{array}$ & TOTAL & $\begin{array}{l}\text { PART } \\
\text { TIME }\end{array}$ & $\begin{array}{l}\text { PART } \\
\text { TIME }\end{array}$ & $\begin{array}{c}\text { TEMP } \\
\text { RATE } \\
\text { PART- } \\
\text { TIME } \\
\text { CONTR }\end{array}$ & TOTAL & $\begin{array}{l}\text { PART- } \\
\text { TIME }\end{array}$ & TOTAL & $\begin{array}{l}\text { PART } \\
\text { TIME }\end{array}$ & $\begin{array}{c}\text { TEMP } \\
\text { RATE } \\
\text { PARTIAL } \\
\text { TIME } \\
\text { CONTR. }\end{array}$ \\
\hline 1995 & 549,838 & 96,210 & 523,629 & 89,331 & 92.85 & 332,441 & 39,915 & 37,015 & 11.13 & 217,397 & 56,295 & 206,231 & 52,316 & 92.93 \\
\hline 1996 & 647,612 & 127,638 & 626,472 & 121,823 & 95.44 & 383,762 & 53,743 & 50,956 & 13.27 & 263,850 & 73,895 & 255,561 & 70,867 & 95.90 \\
\hline 1997 & 803,982 & 168,704 & 732,737 & 159,801 & 94.72 & 470,333 & 70,220 & 65,741 & 13.97 & 333,649 & 98,484 & 307,655 & 94,060 & 95.50 \\
\hline 1998 & 889,064 & 178,996 & 821,639 & 170,189 & 95.07 & 506,839 & 68,785 & 64,917 & 12.80 & 382,225 & 110,211 & 356,681 & 105,272 & 95.51 \\
\hline 1999 & $1,079,368$ & 193,039 & 978,594 & 177,226 & 91.80 & 605,887 & 72,964 & 66,380 & 10.95 & 473,481 & 120,075 & 432,801 & 110,846 & 92.31 \\
\hline 2000 & 977,022 & 179,590 & 889,883 & 162,413 & 90.43 & 535,472 & 65,186 & 58,307 & 10.88 & 441,550 & 114,404 & 404,248 & 104,106 & 90.99 \\
\hline 2001 & 959,514 & 192,751 & 871,519 & 177,714 & 92.19 & 516,284 & 67,516 & 61,493 & 11.91 & 443,230 & 125,235 & 403,747 & 116,221 & 92.80 \\
\hline 2002 & 958,337 & 212,937 & 877,050 & 191,443 & 89.90 & 514,433 & 73,759 & 65,788 & 12.78 & 443,904 & 139,178 & 406,708 & 125,655 & 90.28 \\
\hline 2003 & $1,136,470$ & 262,563 & $1,046,255$ & 237,591 & 90.48 & 601,551 & 89,595 & 80,588 & 13.39 & 534,919 & 172,968 & 492,842 & 157,003 & 90.76 \\
\hline 2004 & $1,223,322$ & 289,238 & $1,131,659$ & 264,039 & 91.28 & 640,576 & 98,835 & 89,660 & 13.99 & 582,746 & 190,403 & 540,053 & 174,379 & 91.58 \\
\hline 2005 & $1,329,617$ & 318,398 & $1,221,137$ & 289,190 & 90.82 & 700,780 & 107,476 & 96,632 & 13.78 & 628,837 & 210,922 & 578,874 & 192,558 & 91.29 \\
\hline 2006 & $1,386,283$ & 331,328 & $1,151,161$ & 278,300 & 83.99 & 732,095 & 110,054 & 93,129 & 12.72 & 654,188 & 221,274 & 552,970 & 185,171 & 83.68 \\
\hline 2007 & $1,261,319$ & 319,002 & $1,126,808$ & 281,844 & 88.35 & 640,935 & 103,937 & 90,729 & 14.15 & 620,384 & 215,065 & 556,434 & 191,115 & 88.86 \\
\hline 2008 & $1,117,577$ & 306,681 & $1,014,516$ & 273,947 & 89.32 & 562,045 & 102,931 & 90,613 & 16.12 & 555,532 & 203,750 & 506,135 & 183,334 & 89.97 \\
\hline 2009 & $1,137,565$ & 322,387 & $1,051,738$ & 292,699 & 90.79 & 594,361 & 114,794 & 102,660 & 17.27 & 543,204 & 207,593 & 503,196 & 190,039 & 91.54 \\
\hline 2010 & $1,189,818$ & 336,013 & $1,096,647$ & 303,255 & 90.25 & 645,330 & 123,514 & 110,285 & 17.08 & 544,488 & 212,499 & 502,005 & 192,970 & 90.80 \\
\hline 2011 & $1,165,465$ & 323,924 & $1,099,787$ & 299,282 & 92.39 & 640,952 & 122,893 & 111,499 & 17.39 & 524,513 & 201,031 & 495,869 & 187,783 & 93.40 \\
\hline 2012 & $1,058,501$ & 343,140 & 981,135 & 309,575 & 90.21 & 576,230 & 134,763 & 122,678 & 21.28 & 482,271 & 208,377 & 442,862 & 186,897 & 89.69 \\
\hline 2013 & $1,290,853$ & 413,501 & $1,207,061$ & 378,243 & 91.47 & 741,220 & 168,969 & 154,526 & 20.84 & 549,633 & 244,532 & 509,713 & 223,717 & 91.48 \\
\hline 2014 & $1,384,062$ & 463,354 & $1,284,209$ & 421,736 & 91.01 & 788,262 & 189,545 & 172,216 & 21.84 & 595,800 & 273,809 & 548,912 & 249,520 & 91.12 \\
\hline 2015 & $1,594,915$ & 526,961 & $1,487,057$ & 483,154 & 91.68 & 904,072 & 214,015 & 195,620 & 21.63 & 690,843 & 312,946 & 640,679 & 287,534 & 91.87 \\
\hline 2016 & $1,699,018$ & 553,488 & $1,576,724$ & 502,933 & 90.86 & 972,807 & 223,442 & 202,068 & 20.77 & 726,211 & 330,046 & 669,774 & 300,865 & 91.15 \\
\hline
\end{tabular}

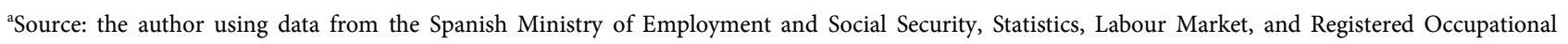
Movements.

and, thus, noticeably affects the amount of pensions paid. In 2015, a woman's mean pension came to 743 euros/month, while that of a man was $1197 \mathrm{eu}-$ ros/month ${ }^{34}$. Working women's impoverishment comes into play not only while they work, but also when they are pensioners. Unfair gender-based discrimina-

${ }^{34}$ Informe sobre la participación laboral de las mujeres en España. CES Sesión ordinaria del Pleno del 21 de diciembre de 2016. 
tion persists in time with an inertia that the lawmaker does not seem to want it end. Part-time work cannot act as a refuge for women by justifying it as a regime that facilitates the conciliation of working and family life: doing away with this it is absolutely necessary to abolish this working life-family life pair by making men also responsible for family life and in equal terms with women, and by making part-time work a useful voluntary instrument for this purpose, among many others, but one on equal terms for both genders.

\section{Finally, Some Statistical Data and a Reflection}

As previously pointed out, today's legal part-time contract system is designed to confer the company a flexible contact adapted to situations when the company sporadically requires workers. All that the vast number of additional hours worked for businesspeople does is to reinforce the idea that this has been the lawmaker's purpose, and available data show that this purpose has certainly been met.

Indeed the evolution of the part-time contract in Spain is quite significant, even though it is necessary to place it in the context of the Spanish labour market's characteristics: high unemployment rates, high temporariness and a high involuntariness rate in part-time work. Back in 1985 there were about 123,849 part-time contracts in absolute number terms, and this figure rose to 358,533 in 1989; 935,428 in 1995; 516,455 in 1996 and in 1997 to 1,859,851, with barely any change over the $1997-2001$ period with $7.9 \%$ in 1997 and $8.2 \%$ in 2001 . After 2001 and with the increase in employment as result of the Spanish property bubble, part-time contracts still reported low rates [12\% (4.3\% males, $23.2 \%$ females ${ }^{35}$ )] compared to other EU countries: $18.1 \%$ EU-27 (7.7\% males, $31.2 \%$ females). The economic recession that began in 2009 strongly impacted the part-time employment rates. This increase can be explained partly by some companies converting full-time jobs into part-time ones: the part-time job rate went from $8 \%$ in 1999 to $12.8 \%$ in 2009 , where females predominated, and then went to $23 \%$ in 2009 , while the same rate for males continued at $4.9 \%{ }^{36}$. The aforementioned part-time rate of $15.7 \%$ in 2013 (males $7.7 \%$, females $25.2 \%$ ) was a marked increase, but was still below UE-27 levels of $19.7 \%{ }^{37}$. The increase in males' part-time work rate ${ }^{38}$ is particularly striking, $18.1 \%$, as opposed to one of $4 \%$ for part-time wage-earner females, which indicates that the growth in part-time work is compulsory in nature ${ }^{39}$ : the percentage of involun-

\footnotetext{
${ }^{35}$ EUROSTAT, European Union Labour Force Survey. Annual results, 2006.

${ }^{36}$ EUROSTAT, European Union Labour Force Survey. Annual results 2009. Part-time contracting also rose in Europe, but at somewhat lower percentages: $18.8 \%$ of UE27 workers did part-time work, which was an increase of almost 3 percentage points in 10 years. During this period in the UE27, the proportion of females who worked part-time rose from $28.5 \%$ to $32.0 \%$, while the increase for male part-time workers went from $6.4 \%$ to $8.3 \%$. The increase in the part-time rate during the recession was similar for both genders (European Company Survey 2009. Part-time work in Europe).

${ }^{37}$ Eurostat. Part-time employment as percentage of the total employment, by sex and age (\%).

${ }^{38}$ Report on Spain's socio-economic and occupational situation in 2013. Passed during the special session held by the Economic and Social Council held on 23 May 2013.

${ }^{39}$ Among the reasons to work part-time, the most frequent one in 2013 was not having been able to find a full-time job, specifically with $62.7 \%$. INE. Survey with the Working population.
} 
tary part-time work ${ }^{40}$ in Spain rose to $61.9 \%$ in 2016 versus $27.7 \%$ in European Union in the same year. These figures sharply contrast with the involuntariness percentage in both UE-27 and UE-28, which was $29.3 \%$ in 2013 . This involuntariness rate is very high among youths: the temporariness of wage-earning youths aged 16 - 19 years in 2016 was $87.5 \%$ per 100 , that of the 20 - 24 year-old group was $71 \%$ and it was $47.8 \%$ for the 25 - 29 age group.

In short, temporary work and part-time work are taken as two main forms of occupational flexibility that has become rooted in our labour market: in 2016 part-time contracts ${ }^{41}$ continued to grow, but more quickly than full-time ones, with $8.7 \%$ and $6.9 \%$ increases, respectively. Indeed part-time contracts represent 7.2 million work contracts, which is more than one third of all registered work contracts $^{42}$. With temporal contracts, part-time work has grown $8.2 \%$, which means that the number of temporary part-time contracts more than doubles that recorded before the crisis. To this it is necessary to add the fact that the duration of temporal contracts is becoming increasingly shorter: in $201526.9 \%$ of temporary contracts were in force for 1 week of less, and this figure rose to $28.1 \%$ of all contracts in 2016.

Thus the tendency of shorter part-time contacts being signed has become well-established in Spain, even in times of economic recovery and job creation. This is not because workers want such contracts, but they clearly have no other options as the involuntariness rate still comes close to two thirds of all the people who work part-time. In 2016 the involuntariness rate ${ }^{43}$ of part-time workers was $61.9 \%$, as opposed to $27.7 \%$ in the EU. This low-quality work will clearly determine workers' impoverishment ${ }^{44}$, and this harm will persist when these workers access the protection allocated from the Social Security system, particularly when they draw their pensions. Part-time work must be an option for workers, and also a good business management tool, but must never become a contracting mode on which to build job creation.

\section{Acknowledgements}

This work has been conducted as part of the Research Project "New forms of accessing employment" as part of the University Jaume I-Castellón Research Pro${ }^{40}$ Involuntary part-time employment as percentage of the total part-time employment, by sex and age (\%).

${ }^{41}$ Report on Spain's socio-economic and occupational situation in 2016. Passed during the regular session held by the Economic and Social Council held on 31 May 2017.

${ }^{42}$ Report on Spain's socio-economic and occupational situation in 2016. Passed during the regular session held by the Economic and Social Council held on 31 May 2017.

${ }^{43}$ Eurostat. Involuntary part-time employment as percentage of the total employment, by sex and age (\%).

${ }^{44}$ The increase in the proportion of wokers in jobs in recent years for part-time work (from $14.5 \%$ in 2012 to $15.6 \%$ in 2015 ) and temporary work (from $23.4 \%$ in 2012 to $25.7 \%$ in 2015 ) has been in parallel with a growing risk of poverty for part-time workers (from $18.7 \%$ in 2013 to $22.9 \%$ in 2014), and for temporary workers (from $17.5 \%$ in 2013 to $22.9 \%$ in 2014). This, along with moderate changes in wages, has contributed to the general increase in the number of poor workers observed in recent years. The 2016 Report on Spain using a thorough examination about preventing and correcting macroeconomic imbalances. The Commission's Services Work Document. Brussels, 26 June 2016, SWD (2016), 78 final. 
motion Plan (2015). (Principal Investigator: S. Ruano-Albertos).

\section{References}

Cabeza Pereiro, J. (2013). EL trabajo a tiempo parcial y las debilidades del modelo español. Bomarzo.

Casas Baamonde, M. E. (2000). Los contratos de trabajo a tiempo parcial: Contrato a tiempo parcial, contrato fijo-discontinuo y contrato de relevo. Revista Española de Derecho del Trabajo, 100.

Cavas Martínez, F. (2001). El nuevo contrato de trabajo a tiempo parcial. en AAVV., La reforma laboral de 2001. Aranzadi.

Escudero Rodríguez, R. (2001). Propósitos y despropósitos de la reforma laboral de 2001. en Relaciones Laborales, 10.

Garcia Ninet, J. I., \& Vicente Palacio, M. A. (2013). Trabajo a tiempo parcial y acceso al sistema español de Seguridad Social: el caso Elbal Moreno. Revista del Ministerio de Empleo y Seguridad Social, 102.

Goerlich Peset, J. M. (2001). La reforma de la contratación laboral: Tiempo parcial y contratos de duración determinada. en AAVV, la reforma laboral en el Real Decreto-Ley 5/2001, Tirant lo Blanch, Valencia.

Rodríguez-Piñero y Bravo Ferrer, M. (1985). Las modalidades de contratación laboral en el Estatuto de los Trabajadores reformado. Relaciones Laborales, 1.

Rodríguez-Piñero y Bravo Ferrer, M., Valdés Dal-Ré, F., \& Casas Baamonde, M. E. (2014). Contratación a tiempo parcial y flexibilidad del tiempo de trabajo en la nueva reforma laboral (RDL 16/2013, de 20 de diciembre). Relaciones Laborales, 2.

Ruano Albertos, S. (2017). El contrato a tiempo parcial: Las posibles perversiones en su utilización. Revista General de Derecho del Trabajo y de la Seguridad Social, 46. 